\title{
Thickness and density of snow-covered sea ice and hydrostatic equilibrium assumption from in situ measurements in Fram Strait, the Barents Sea and the Svalbard coast
}

\author{
Sanja FORSSTRÖM, Sebastian GERLAND, Christina A. PEDERSEN \\ Norwegian Polar Institute, Fram Centre, NO-9296 Tromsø, Norway \\ E-mail: sanja.forsstrom@npolar.no
}

\begin{abstract}
Modern satellite measurements of sea-ice thickness are based on altimeter measurements of the difference in elevation between the snow or ice surface and the local sea surface. For retrieval of seaice thickness, it is assumed that the ice is in hydrostatic equilibrium, and that the snow load on the ice and the density of the sea ice and sea water are known. This study presents data from in situ sea-ice thickness drillings and snow and ice density measurements from Fram Strait, the Barents Sea and the Svalbard coast, in the European Arctic. The error in the altimetry ice thickness products is assessed based on the spatial variability of snow and ice density and snow thickness data. Ice thickness uncertainty related to snow depth was found to be $\sim 40 \mathrm{~cm}$ (radar altimeter) and $\sim 90 \mathrm{~cm}$ (laser altimeter), while uncertainty related to ice density is $25 \mathrm{~cm}$ for both techniques. The assumption of hydrostatic equilibrium at the scales of the measurements $(10-100 \mathrm{~m})$ was found to hold better in the case of level landfast ice near Svalbard than for Fram Strait drift ice, which consists of mixed ice types, where the deviation between the calculated and measured ice thicknesses was on average $\sim 0.5 \mathrm{~m}$.
\end{abstract}

\section{INTRODUCTION}

Sea-ice extent and concentration are monitored routinely using passive microwave techniques (e.g. Gloersen and Campbell, 1991; Johannessen and others, 1999). Ice thickness, which is the second factor in the total sea-ice volume, and hence the Arctic sea-ice mass-balance estimates, is more complicated to obtain from satellite observations (Sandven and Johannessen, 2006). Fram Strait is by far the most important passage for sea-ice export from the Arctic. Therefore thickness estimates from this area are of special scientific interest.

The common approach to determining sea-ice thickness from satellites is via measurement of the elevation difference between the ice and the water surface (freeboard, $h_{f}$ ), or the snow and the water surface (the sum of freeboard and snow thickness, $h_{\mathrm{s}}$, here called snow freeboard, $h_{\mathrm{sf}}=h_{\mathrm{f}}+h_{\mathrm{s}}$ ). The two types of satellite altimeters utilized for freeboard/snowfreeboard detection are radar (Laxon and others, 2003; Giles and others, 2008a,b) and, more recently, laser-based altimeters (Kurtz and others, 2009; Kwok and Rothrock, 2009; Spreen and others, 2009). Both give promising spatial and temporal patterns consistent with submarine data, but also present challenges, discussed below.

Radar altimeters detect $h_{\mathrm{f}}$, assuming a snow layer transparent to microwaves. Laser pulses instead reflect from the snow surface, and therefore laser altimeters yield $h_{\mathrm{sf}}$. The conversion to ice thickness, $h_{\mathrm{i}}$ (Equation (1) for radar and Equation (2) for laser), is based on the assumption that the freeboard and snow freeboard are determined by the hydrostatic balance:

$$
h_{\mathrm{i}}=\frac{\rho_{\mathrm{w}}}{\rho_{\mathrm{w}}-\rho_{\mathrm{i}}} h_{\mathrm{f}}+\frac{\rho_{\mathrm{s}}}{\rho_{\mathrm{w}}-\rho_{\mathrm{i}}} h_{\mathrm{s}}
$$

and

$$
h_{\mathrm{i}}=\frac{\rho_{\mathrm{w}}}{\rho_{\mathrm{w}}-\rho_{\mathrm{i}}} h_{\mathrm{sf}}+\frac{\rho_{\mathrm{s}}-\rho_{\mathrm{w}}}{\rho_{\mathrm{w}}-\rho_{\mathrm{i}}} h_{\mathrm{s}}
$$

Assumptions about the snow conditions (thickness, $h_{\mathrm{s}}$ and density, $\left.\rho_{\mathrm{s}}\right)$, as well as the sea-ice and sea-water densities $\left(\rho_{\mathrm{i}}\right.$ and $\rho_{\mathrm{w}}$, respectively), are therefore needed.

Due to the labour-intensive nature of data collection and the remote locations of interest, both in situ drilling data and data about snow conditions on sea ice in the High Arctic are sparse. Some earlier published work concentrated on detailed studies of individual ice features (e.g. Melling and others, 1993; Bowen and Topham, 1996; Timco and Burden, 1997) or drillings for calibration/validation of sounding techniques for freeboard or draft (e.g. Haas, 2004; Haas and others, 2006). The most extensive dataset on drillings and snow conditions on sea ice resulted from Soviet drifting stations and Sever flights (1928-93) (Romanov, 1996). Warren and others (1999) (War99 henceforth) compiled the drift station (1954-91) snow data, while Alexandrov and others (2010) reviewed the drill measurement data from the Russian Arctic in the 1980s.

Here we present a new set of in situ sea-ice data from thickness drillings, including density measurements of sea ice and snow. The data were collected on drift ice in Fram Strait and the Barents Sea, and on fast ice along the Svalbard coast in the years 1999-2008. Snow and sea-ice thickness and density distributions are presented.

A freely floating ice floe as a whole is in hydrostatic equilibrium, whereas on a point-to-point basis the equilibrium does not necessarily hold (Doronin and Kheisin, 1977). In drift ice, forces caused by mechanical processes with neighbouring ice floes can cause the ice to be out of hydrostatic equilibrium; the same can happen with landfast ice due to interactions with the shore and bottom. In this study, the deviation from hydrostatic balance is examined using drillings aimed at describing the thickness distribution of a floe. The sensitivity of the $h_{\mathrm{i}}$ product with the hydrostatic assumption to the uncertainties of the densities, $\rho_{\mathrm{i}}, \rho_{\mathrm{s}}$ and $\rho_{\mathrm{W}}$, and the snow thickness, $h_{\mathrm{s}}$, is also presented. 
Table 1. Data overview. Number of thickness drillings for sea ice, snow and freeboard $\left(h_{\mathrm{i}}, h_{\mathrm{s}}, h_{\mathrm{f}}\right)$ and column measurements of sea-ice and snow densities $\left(\rho_{\mathrm{i}}, \rho_{\mathrm{S}}\right)$. The number of ice-station sites at which the measurements were conducted is given in parentheses. The sources given in the last column include some of the data and description of the expedition in question. Some of the data have not been published before

\begin{tabular}{|c|c|c|c|c|c|c|}
\hline Location & Month & Year & $h_{\mathrm{i}}, h_{\mathrm{s}}, h_{\mathrm{f}}$ & $\rho_{\mathrm{i}}$ & $\rho_{\mathrm{s}}$ & Source \\
\hline Barents Sea & May & 1999 & $44(9)$ & 0 & $7(7)$ & Ivanov and others (2003) \\
\hline Fram Strait & May-Jul. & 2005 & $115(18)$ & 1 & $24(24)$ & Gerland and others (2006); Pedersen and others (2009) \\
\hline Fram Strait & Apr. & 2007 & $140(23)$ & $5(4)$ & $9(9)$ & \\
\hline Fram Strait & Apr.-May & 2008 & $117(27)$ & $12(8)$ & $23(23)$ & \\
\hline Fram Strait & Sep. & 2003 & $6(2)$ & 0 & 0 & Hansen and others (2004) \\
\hline Fram Strait & Sep. & 2004 & $19(7)$ & 0 & $3(3)$ & \\
\hline Fram Strait & Aug.-Sep. & 2005 & $40(12)$ & 0 & 0 & \\
\hline Fram Strait & Sep. & 2006 & $30(8)$ & 0 & $9(9)$ & \\
\hline Fram Strait & Sep. & 2007 & $31(8)$ & $11(8)$ & $7(7)$ & \\
\hline Fram Strait & Sep. & 2008 & $11(6)$ & 0 & 0 & \\
\hline Hopen & Feb.-May & 2008 & $107(36)$ & 0 & 0 & Gerland and others (2008a) \\
\hline Storfjorden & Jan.-Mar. & 2007 & $78(46)$ & 0 & 0 & Gerland and others (2008b) \\
\hline Kongsfjorden & Apr., Jun. & 2003 & $20(14)$ & 0 & 0 & Gerland and others (2008b); Gerland and Renner, 2007 \\
\hline Kongsfjorden & Jan.-Jun. & 2004 & $44(5)$ & 0 & 0 & $\begin{array}{c}\text { Gerland and Hall (2006); Gerland and Renner (2007) } \\
\text { Gerland and others (2008b) }\end{array}$ \\
\hline Kongsfjorden & Feb.-Apr. & 2005 & $21(4)$ & 0 & 0 & Gerland and Renner (2007); Gerland and others (2008b) \\
\hline Kongsfjorden & May & 2006 & $25(3)$ & 0 & 0 & Gerland and others (2008b) \\
\hline Kongsfjorden & Mar. & 2007 & $22(1)$ & 0 & 0 & Gerland and others (2008b) \\
\hline Kongsfjorden & Jan.-Apr., Jul. & 2008 & $232(11)$ & 0 & 0 & \\
\hline Krossfjorden & May & 2006 & $104(4)$ & 0 & 0 & \\
\hline Total & & & $1206(244)$ & $29(21)$ & $82(82)$ & \\
\hline
\end{tabular}

\section{BACKGROUND}

Sea-ice and snow properties are known to vary on the scales of the spatial resolution of altimeter data, which is $2-10 \mathrm{~km}$ for the Envisat RA-2 radar (Connor and others, 2009), $70 \mathrm{~m}$ for the Ice, Cloud and land Elevation Satellite (ICESat) Geoscience Laser Altimeter System (GLAS) (Kurtz and others, 2009) and $250 \mathrm{~m}$ for the CryoSat-2 Synthetic Aperture Radar Interferometric Radar Altimeter (SIRAL) (http:// esamultimedia.esa.int/multimedia/publications/BR199_LR. pdf). Integrations performed over these large footprints require knowledge of the distributions of snow and ice parameters at these scales. Furthermore, estimation of the uncertainty related to the deviations from the assumed snow and ice parameters necessitates knowledge of their variation at larger scales.

For estimating $h_{\mathrm{s}}$ on Arctic sea ice, the climatology of War99 is most often used. However, this climatology does not cover Fram Strait, and might not represent recent conditions in the rapidly changing Arctic. The other approaches under development for estimating the snowpack on sea ice are: (1) passive microwave techniques with instruments such as the Advanced Microwave Scanning Radiometer (AMSR-E) on board Earth Observing System (EOS) Aqua (Kurtz and others, 2009), (2) concurrent measurements by laser and radar altimetry and (3) model precipitation analysis. Both (1) and (2) suffer from difficulties in combining measurements with very different spatial resolutions. All three techniques require ground data for validation.

Traditionally, the densities, $\rho_{\mathrm{s}}, \rho_{\mathrm{i}}$ and $\rho_{\mathrm{W}}$, in the altimetrybased $h_{\mathrm{i}}$ calculation are kept constant. Other approaches include the formula by Kovacs (1997) for $\rho_{\mathrm{i}}$ dependence on ice thickness, and the $\rho_{\mathrm{s}}$ seasonal cycle based on War99 climatology. A constant value for the sea-water density, which exhibits relatively little variation in nature, is generally used (Laxon and others, 2003; Kwok and Cunningham, 2008; Spreen and others, 2009).

Laser altimeters have an order-of-magnitude higher spatial resolution than radar altimeters, but are also more sensitive to uncertainty in the measured freeboard. Radar altimetry is better established as a technique, but large challenges remain, especially in understanding the interference of the radar signal with different surfaces, such as in cases with negative freeboard, snow/ice, superimposed ice and ice layers within the snowpack. Both radar and laser altimetry suffer from uncertainty due to the unknown snow load (Giles and others, 2007) and the challenge of defining the local sea-ice surface. Simulations by Tonboe and others (2009) show that variability of the radar penetration and the error caused by preferential sampling of certain ice types are error sources as important for radar altimetry as the uncertainties in the parameters affecting the floe buoyancy. Field data on the distribution and temporal variability of sea-ice density, ice types and the density and depth of snow on the ice are essential for validating and calibrating any satellite-based $h_{\mathrm{i}}$ products.

The data from the Fram Strait area are particularly valuable for two reasons. First, the ice conditions result both from ice advection and local processes, and are particularly complex due to the strong southward flow. Second, the ice thickness distribution in Fram Strait is of interest as it is the main passage for meridional ice transport from the Arctic basin.

\section{IN SITU SEA-ICE MEASUREMENTS}

The dataset presented here consists of in situ drill-hole measurements of ice, snow and freeboard thicknesses (Table 1). Ice densities from sea-ice cores and snow densities from pit studies are also included. The data were collected during several spring and autumn field campaigns in the 

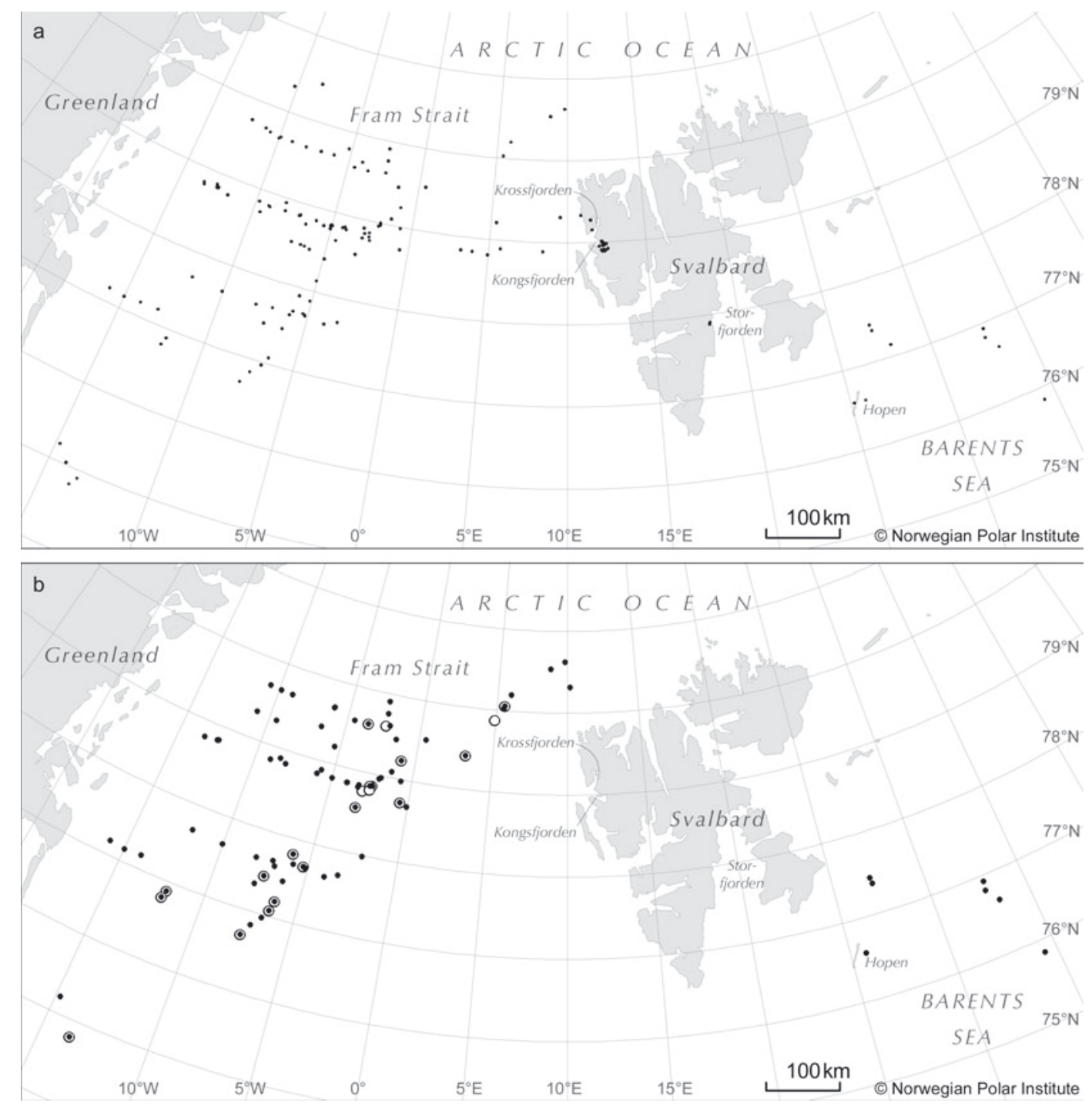

Fig. 1. (a) The ice stations with thickness drillings providing measurements of ice thickness, snow depth and ice freeboard. (b) The ice stations where, in addition to the thickness drillings, snow density (dots) or ice density (circles) were also measured.

years 1999-2008. Landfast sea ice in Spitsbergen fjords, coastal sea ice of Svalbard and drift ice in Fram Strait and the Barents Sea (Fig. 1) are all included.

Typically at an ice-station site, a snow-pit study is conducted to provide the vertical stratigraphy, temperature and density profiles in the snow on the sea ice. Ice corings for temperature, salinity, chlorophyll content and, often, for density are conducted. Thickness drilling transects including snow depth, sea-ice thickness and freeboard measurements, spanning up to $500 \mathrm{~m}$ in length, are performed. The typical interval of drillings along a transect is $5-35 \mathrm{~m}$. Each ice station consists of 1-31 (typically 5) measurements of ice and snow thicknesses (Table 1). The location and orientation of the transects are chosen to be the most representative of conditions on the floe. Naturally, the regions of thinnest ice are not investigated since the ice must be thick enough to safely work on. Also, the limited number of drillings might not capture the thickness distribution over the whole floe. For further calculations the data are averaged over an ice floe site, which means averaging over the scales of $10-500 \mathrm{~m}$. The actual thickness reading has an uncertainty of $1 \mathrm{~cm}$.

The thickness drillings are conducted using, typically, $5-10 \mathrm{~cm}$ diameter drills. For ice density, the core pieces, typically $10 \mathrm{~cm}$ long, are weighed and the mean density for the site is calculated as an average weighted by the length of each core piece. Sea-ice density measurements made by weighing the core are often subject to a negative bias due to the loss of some of the brine content and deviation from the ideal form (in this case cylindrical) of the sample (Timco and Frederking, 1996). The uncertainty in the density measurements is $\sim 15 \mathrm{~kg} \mathrm{~m}^{-3}$.

For snow density, a known volume $\left(0.5 \mathrm{dm}^{3}\right)$ of snow is collected using a density probe inserted horizontally into the wall of a snow pit, and then weighed. The measurement is repeated along a vertical profile through the snowpack. A weighted average based on the measurement depths is calculated to obtain the mean density through the snowpack. For snow density measurement, the largest cause of bias is the difficulty in filling the density probe without compressing or losing any snow. The estimated uncertainty for $\rho_{\mathrm{s}}$ measurement is $\sim 50 \mathrm{~kg} \mathrm{~m}^{3}$.

\section{RESULTS AND DISCUSSION}

The probability density functions (PDFs) calculated for the mean ice (Fig. $2 \mathrm{a}-\mathrm{C}$ ) and snow thickness (Fig. $2 \mathrm{~d}-\mathrm{f}$ ) at the ice 

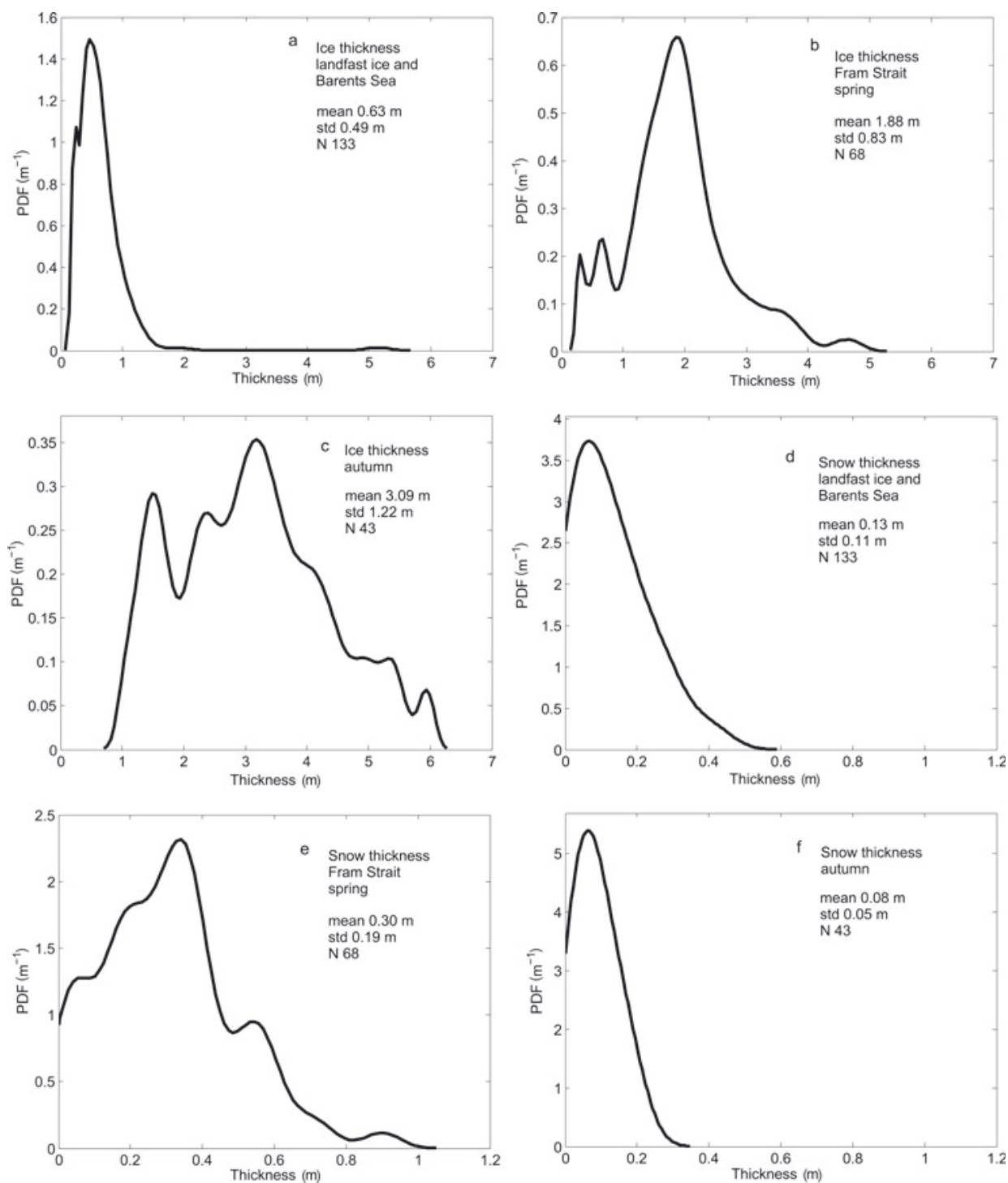

Fig. 2. PDFs for sea-ice thickness $(\mathrm{a}-\mathrm{c})$ and snow-depth $(\mathrm{d}-\mathrm{f})$ data pooled to Barents Sea and landfast ice at Svalbard coast (all data collected in spring; a, d), Fram Strait (only spring data; b, e), autumn data (all data collected in Fram Strait; c, f). Mean, standard deviation (std) and number of ice stations $(N)$ for different pools are indicated. Smoothing window bandwidths of $0.15 \mathrm{~m}$ (for ice thickness) and $0.05 \mathrm{~m}$ (for snow depth) were applied.

stations show the characteristics of the different regions and seasons: landfast ice in Svalbard and drift ice in the Barents Sea (all measurements conducted in spring; Fig. 2a and d), spring data from Fram Strait (Fig. 2b and e) and all autumn data (Fig. 2c and f). The data are divided into (1) Fram Strait and (2) eastern data (Svalbard coast and Barents Sea) because (1) is a region characterized by strong ice advection, whereas in (2) the ice evolution is expected to be less influenced by ice-dynamic processes. Note that the measurements taken in autumn are solely from Fram Strait. A non-parametric kernel smoothing regression is used for the PDF estimates.

\section{Ice properties}

The sea ice in Fram Strait contains ice of various ages transported south from the Arctic basin, as well as some locally formed young ice. Therefore the $h_{\mathrm{i}}$ is relatively broadly distributed over the thickness range (Fig. 2b), whereas for the landfast ice around Svalbard and the ice in the Barents Sea (Fig. 2a), the PDF is skewed toward the smallest $h_{\mathrm{i}}$. The average $h_{\mathrm{i}}$ for Fram Strait is $2.35 \mathrm{~m}$ (averaged over both seasons), whereas for Svalbard and the Barents Sea it is $0.63 \mathrm{~m}$. The measurements in Fram Strait can be considered representative as they compare well with the earlier reported thicknesses from Fram Strait (Vinje and others, 1998, table 3).

Despite the small number of data points, the thicknessdrilling data from the Barents Sea compare well with the drafts reported by Abrahamsen and others (2006) from mooring upward-looking sonar measurements in the years 1995-96. In the comparison, one needs to account for the thinnest ice, missing in the in situ data. In 1995, the mean draft was $\sim 0.5 \mathrm{~m}$ thicker and in 1996 it was very similar to our measurements in 1999. As pointed out by Abrahamsen and others (2006), sea-ice conditions in the Barents Sea can experience large interannual variability.

The autumn ice thickness data (Fig. 2c, all collected in Fram Strait) are sparse compared with the spring dataset and are dominated by multi-year ice. No thin first-year ice is present in the autumn data, and therefore the average thickness is $>3 \mathrm{~m}$. For spring the average $h_{\mathrm{i}}$ is $<2 \mathrm{~m}$. 


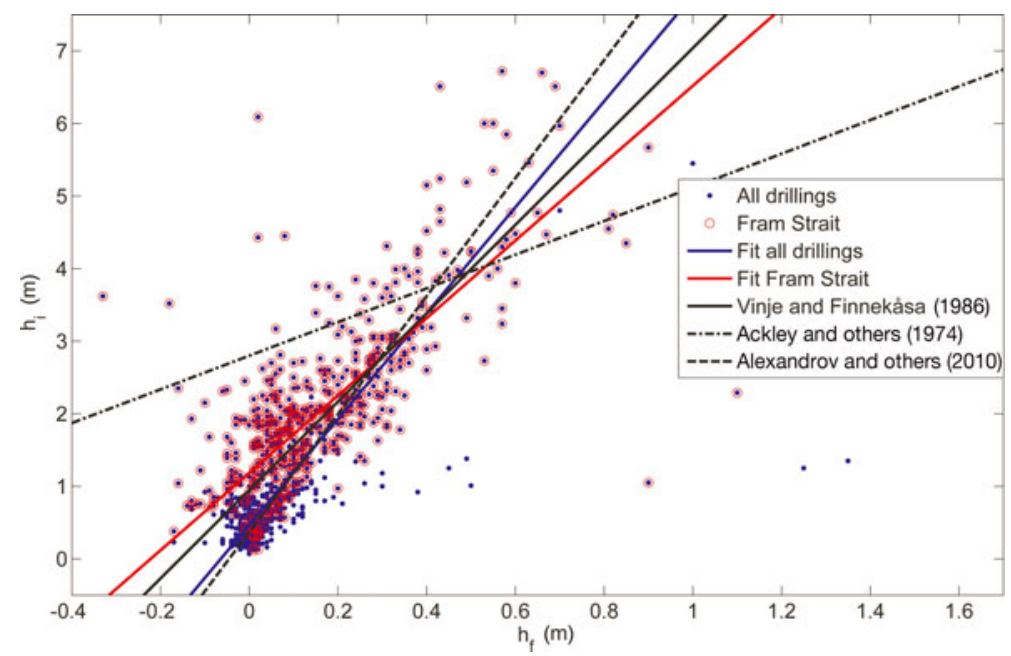

Fig. 3. In situ ice thickness as a function of freeboard (dots denote all drillings from this study, circles drillings in Fram Strait), together with linear robust fits $\left(h_{\mathrm{i}_{\text {fit }}}=7.37 h_{\mathrm{f}}+0.44(\mathrm{~m})\right.$ and $h_{\mathrm{i}_{\mathrm{fit}}}$ (FramStrait) $\left.=5.34 h_{\mathrm{f}}+1.19(\mathrm{~m})\right)$ The black lines are previously published relationships from corresponding in situ data. Many factors, such as the fitting method, the location, timing and method of measurements, differ from those used in this study.

A more detailed view of the seasonal evolution of $h_{\mathrm{i}}, h_{\mathrm{f}}$ and $\rho_{\mathrm{i}}$, independent of year and region, is presented in Table 2. The thickness maximum due to thermodynamic growth is reached in late spring, which shows up as a sub-maximum of $h_{\mathrm{i}}$ in April-May. Similar timing for the $h_{\mathrm{i}}$ maximum in Fram Strait is reported by Vinje and others (1998). They observed the ice thickness minimum to occur in September, which in our dataset, on the contrary, is during the season with the greatest thickness.

Linear robust fits between $h_{\mathrm{f}}$ and $h_{\mathrm{i}}$ from the thickness drillings (Fig. 3) correspond very well with the work of Ackley and others (1976), Vinje and Finnekåsa (1986) and Alexandrov and others (2010). Figure 3 demonstrates the difference between regions in the Arctic Ocean, as the two datasets collected in the Fram Strait area (Vinje and Finnekåsa, 1986, and this study) are more congruent to each other than to Alexandrov and others (2010) and Ackley and others (1976), whose data are from the Russian Arctic and Beaufort Sea, respectively. The results reported by Vinje and Finnekåsa (1986) were obtained from 382 drillings on level ice (not on ridges) during summer months (July-August, 1981-84). Despite the difference in the timing and method, their slope and ours compare well.
The initial density of the sea ice depends on the conditions whilst freezing. The change in the volume fraction of brine and gases is the mechanism through which $\rho_{\mathrm{i}}$ decreases in growing and ageing ice (Kovacs, 1997). This evolution appears only weakly when plotting $\rho_{\mathrm{i}}$ against $h_{\mathrm{f}}$ (Fig. 4).

The ice density data consist of both first- and multiyear ice in 29 ice cores from Fram Strait, with an average column density of $901.9 \mathrm{~kg} \mathrm{~m}^{-3}$, which is lower than the mean of previously reported values $\left(910 \mathrm{~kg} \mathrm{~m}^{-3}\right.$; Timco and Frederking, 1996). Fram Strait ice contains some thin newly formed ice, but has a large fraction of multi-year ice. This explains the low densities and perhaps also the relatively high variability (standard deviation between the ice stations $22 \mathrm{~kg} \mathrm{~m}^{-3}$ ). Generally, the variability of $\rho_{\mathrm{i}}$ can be expected to be an order of magnitude smaller than that of $\rho_{\mathrm{s}}$.

A comparison of measured and calculated ice thickness (using hydrostatic equilibrium, Equation (1)) is shown in Figure 5. The absolute deviation between the measured and calculated thickness in Fram Strait is, on average, $49 \mathrm{~cm}\left(23 \%\right.$ of measured $\left.h_{\mathrm{i}}\right)$. In the case of thin first-year ice created by thermodynamic growth without significant dynamic disturbance, the calculated ice thickness mimics the measured one well (Fig. 5a). The deviations between

Table 2. Ice thickness, $h_{\mathrm{i}}(\mathrm{cm})$, freeboard, $h_{\mathrm{f}}(\mathrm{cm})$ and density, $\rho_{\mathrm{i}}\left(\mathrm{kg} \mathrm{m}^{-3}\right) . N$ is the number of measurements (stations) in this study 1999-2008. The measurements are averaged over an ice station before calculating the mean and the standard deviation (std)

\begin{tabular}{|c|c|c|c|c|c|c|c|c|c|c|c|c|}
\hline & \multicolumn{12}{|c|}{ Month } \\
\hline & Aug. & Sep. & Oct. & Nov. & Dec. & Jan. & Feb. & Mar. & Apr. & May & Jun. & Jul. \\
\hline$h_{\mathrm{i}}$ mean & 347.5 & 304.1 & - & - & - & 43.1 & 58.2 & 71.8 & 133.6 & 125.7 & 87.6 & 123.0 \\
\hline$h_{\mathrm{i}}$ std & 57.0 & 128.0 & - & - & - & 20.0 & 21.1 & 26.5 & 80.5 & 108.3 & 44.9 & 99.0 \\
\hline$h_{\mathrm{f}}$ mean & 36.5 & 29.8 & - & - & - & -1.0 & 1.4 & 12.5 & 9.7 & 8.0 & 2.8 & 8.5 \\
\hline$N$ & 0 & $11(8)$ & 0 & 0 & 0 & 0 & 0 & 0 & $7(6)$ & $10(7) ?$ & $1(1)$ & 0 \\
\hline$\rho_{\mathrm{i}}$ mean & - & 899.9 & - & - & - & - & - & - & 892.8 & 909.7 & 903.8 & - \\
\hline$\rho_{\mathrm{i}} \mathrm{std}$ & - & 17.6 & - & - & - & - & - & - & 18.9 & 26.9 & 0 & - \\
\hline
\end{tabular}




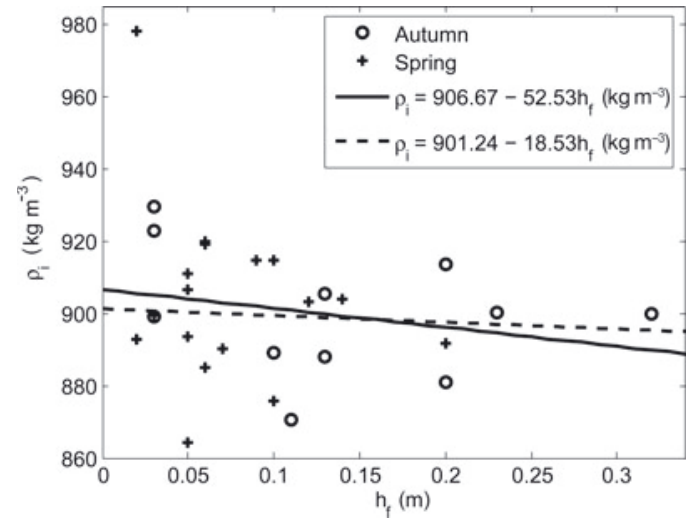

Fig. 4. Sea-ice densities as a function of freeboard for 29 cores from Fram Strait, 2005-08. The linear fit (solid line) is strongly influenced by the exceptionally high data point in the lower part of the $h_{\mathrm{f}}$ range. Applying a robust linear fit (dashed line) yields a weaker dependence between ice density and freeboard.
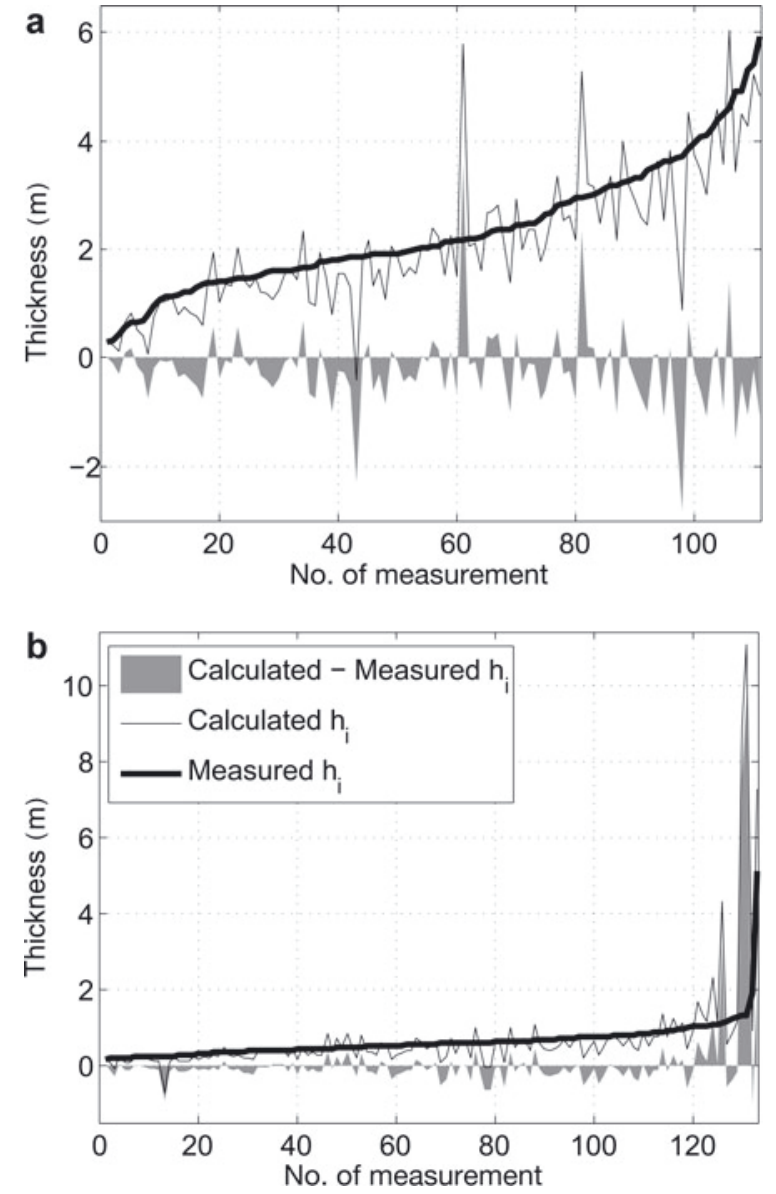

Fig. 5. The measured sea-ice thickness (thick curve) and the ice thickness calculated assuming hydrostatic equilibrium (thin curve) for (a) Fram Strait and (b) the Barents Sea and the landfast sea ice at the Svalbard coast. The in situ measured snow and freeboard thicknesses averaged over an ice station (scales of 10-100 m) are used for calculation. The sea-water density was set to $1024 \mathrm{~kg} \mathrm{~m}^{-3}$ and the snow and sea-ice densities to the averages of the data in this study. The grey area shows the difference between the measured and calculated ice thicknesses. In both graphs the data are sorted by measured ice thickness.
Table 3. Ratio $R$ calculated for the thickness data for the whole dataset and the different regions. The data are averaged over the ice stations prior to the calculation (Equation (3)). The literature values from Wadhams and others (1992) (Wad92) and Comiso and others (1991) (Com91) are added for comparison

\begin{tabular}{lcc}
\hline & $R$ & Source \\
\hline All data & 11.4 & Present study \\
Landfast ice and Barents Sea & 12.0 & $\begin{array}{c}\text { Present study } \\
\text { Fram Strait }\end{array}$ \\
$\begin{array}{lcc}\text { Fram Strait } & 11.2 & \text { Present study } \\
& & \text { Wad 92 } \\
\text { (excluded data) }\end{array}$ \\
$\begin{array}{l}\text { North from Greenland and Fram Strait } \\
\text { North from Greenland }\end{array}$ & 7.89 & Wad92 \\
\hline
\end{tabular}

the measured and calculated $h_{\mathrm{i}}$ increase slightly toward the thicker part of the thickness range, where the dynamics play a more prominent role. On ridged multi-year ice a larger number of drillings is needed for a representative picture of the thickness distribution. The peaks in Figure 5a indicate the cases where drillings were conducted close to or at a pressure ridge.

Due to the thinner ice along the Svalbard coast and in the Barents Sea, the deviation from the hydrostatic equilibrium assumption is more critical for their thickness estimate than in the case of the thicker ice in Fram Strait. The measured and calculated ice thicknesses for the Svalbard coast and Barents Sea differ by $36 \mathrm{~cm}$, on average, which is less than three-quarters of the deviation in Fram Strait, but is $48 \%$ of measured $h_{\mathrm{i}}$ in the area. Purely thermodynamic ice development occurs rarely, but snow-to-ice transformation (Nicolaus and others, 2003; Gerland and others, 2004) complicates the ice evolution and makes the differentiation of snow and ice more convoluted. The landfast ice sites located in protected fjords (Krossfjorden and Kongsfjorden, Svalbard west coast, Fig. 1) are often protected from strong winds and large-scale drift ice motion. Therefore the calculated $h_{\mathrm{i}}$ mimics the measured $h_{\mathrm{i}}$ better for the Svalbard landfast sites and the Barents Sea than for Fram Strait (Fig. 5). However, a small absolute error is of more importance for thin coastal ice than for thick ice in Fram Strait.

The proximity of the shore and the shallowness of the water bring about particular dynamics affecting the ice freeboard. An example is a situation experienced at Hopen (Fig. 1; Gerland and others, 2008a), where the ice packed toward the shoreline by winds was resting on the bottom. In cases like this (the rightmost values in Fig. 5b), the ice freeboard is not determined by the water buoyancy, so the difference between the measured and calculated ice thicknesses becomes much higher than in cases of pressure ridges (Fig. 5a). This situation is exceptional and occurs only in locations shallower than the draft of the drift ice.

\section{Ratio $R$}

The ratio of mean draft to mean freeboard, $R$ (Wadhams and others, 1992; Wad92 hereafter),

$$
R=\frac{\left\langle h_{\mathrm{i}}-h_{\mathrm{f}}\right\rangle}{\left\langle h_{\mathrm{f}}\right\rangle},
$$


Table 4. Snow thickness, $h_{\mathrm{S}}(\mathrm{cm})$, density, $\rho_{\mathrm{S}}\left(\mathrm{kg} \mathrm{m}^{-3}\right)$, and water equivalent, SWE (cm), compared with the quadratic fit of the snow climatology by Warren and others (1999) (War99) for the whole Arctic, 1954-91. N is the number of measurements (stations) of this study, 1999-2008. The $h_{\mathrm{S}}$ measurements are averaged over an ice station before calculating the mean and standard deviation (std). For $\rho_{\mathrm{s}}$ and SWE, only one measurement per ice station was conducted

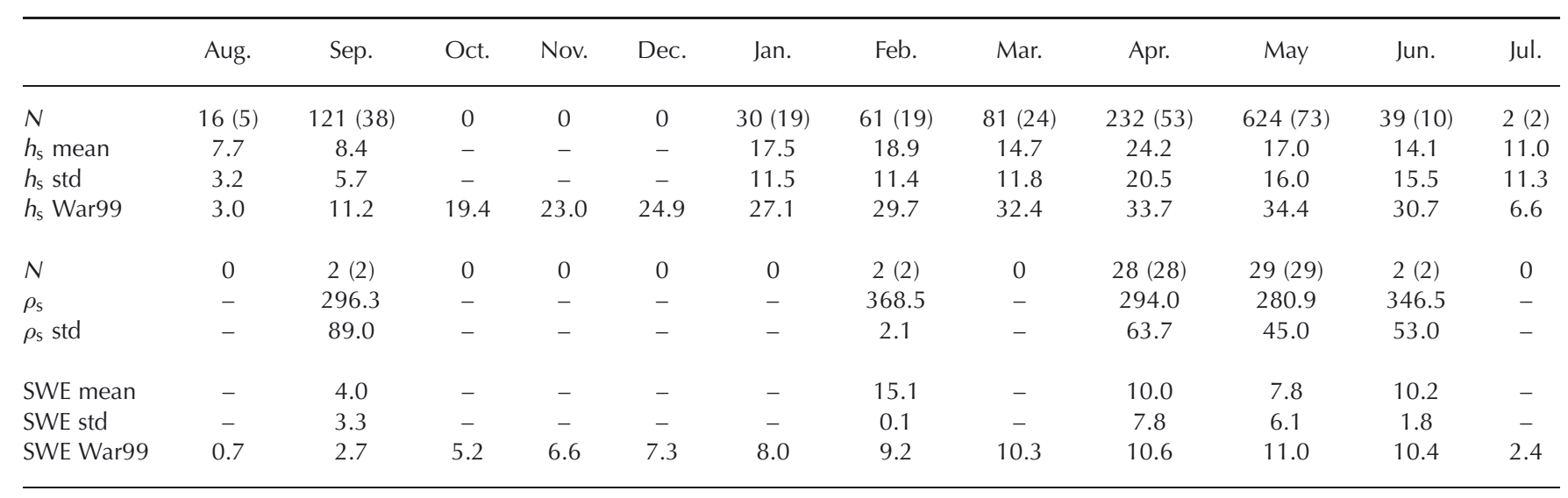

should be related to the densities of sea ice, snow and sea water by

$$
R=\frac{\rho_{\mathrm{i}} h_{\mathrm{i}}+\rho_{\mathrm{s}} h_{\mathrm{s}}}{h_{\mathrm{i}}\left(\rho_{\mathrm{W}}-\rho_{\mathrm{i}}\right)+h_{\mathrm{s}}\left(\rho_{\mathrm{w}}-\rho_{\mathrm{s}}\right)} .
$$

The ratio $R$ is used to describe a certain ice environment, and, furthermore, in the prediction of $h_{\mathrm{i}}$ from freeboard. It is not constant, but needs to be tuned for different ice thickness categories; it also varies between seasons and regions (Wad92; Haas and others, 2006; Tonboe and others, 2009). The ratio calculated for the data from the present study is much higher than $R$ reported earlier for adjacent regions from joint airborne laser and submarine sonar profiles in 1987 by Wad92 and Comiso and others (1991) (Table 3). In their study, Wad92 excluded data they collected in Fram Strait, stating that the displacement between the draft and freeboard datasets was large. In an area with such heterogeneous ice conditions, the displacement caused their $R$ to deviate significantly from the $R$ in more northern study sections. There is no displacement of the draft and freeboard in our data, but the area-averaging of all the parameters causes $R$ to be large (Table 3), yielding unrealistically high densities (according to Equation (4)) for the floating ice.

\section{Snow conditions}

The snow measurements from this study are compared with the climatology of War99 (Table 4). Our study area being south of the region covered by the climatology, differences in climatic conditions between the Soviet NP-stations in War99 and the sites of the present investigation are likely to be significant. Table 4 shows the $h_{\mathrm{s}}, \rho_{\mathrm{s}}$ and snow water equivalent calculated for different months, independent of year. It is apparent that the data are collected during several field seasons at various locations instead of monitoring the snowpack evolution at one site. Figure 2 shows the PDFs for the observed snow thicknesses. Snow thicknesses in the autumn average $8 \mathrm{~cm}$ (Fig. 2f), whereas the spring snow layer on the sea ice is $19 \mathrm{~cm}$ thick on average. As Figure 2e shows, the Fram Strait sea-ice $h_{\mathrm{s}}$ varies greatly (std dev. $19 \mathrm{~cm}$ ); this is due to the wind redistribution on an uneven surface. As the sea ice in Fram Strait originates from different regions in the Arctic, the different floes have different weather histories, which is one cause of variability.

On the landfast sea ice and the Barents Sea the snow cover is notably thinner $\left(h_{\mathrm{s}}=13 \mathrm{~cm}\right.$ on average), and varies less than on the Fram Strait ice, most likely due to the even ice surface and shorter accumulation season (Fig. $2 \mathrm{~d}$ and e). The spring $h_{\mathrm{s}}$ in this study are significantly lower than those found by War99 in the central Arctic (Table 4) during 1954-91. The difference is largest for the months with highest $h_{\mathrm{s}}$ and less pronounced in the autumn data. Potential explanations for lower $h_{\mathrm{s}}$ in our data could be the warmer locations, implying more melting and (together with thinner ice) more snow-toice transformation.

The column snow densities average $292.5 \mathrm{~kg} \mathrm{~m}^{-3}$ (relative std dev. 0.2), which compares closely to the annual average of $300 \mathrm{~kg} \mathrm{~m}^{-3}$ over the Arctic basin reported by War99, increasing from $250 \mathrm{~kg} \mathrm{~m}^{-3}$ in September to $320 \mathrm{~kg} \mathrm{~m}^{-3}$ in May. Besides this seasonal variation, they reported that $\rho_{\mathrm{s}}$ exhibited little geographical variation across the Arctic. The small-scale variation of $\rho_{\mathrm{s}}$, typical for snow parameters due to various depositional (wind and humidity conditions during snowfall) and post-depositional processes (redistribution by snowdrift, snow metamorphosis), is apparent in our data.

\section{Uncertainty of $h_{\mathrm{i}}$ estimate}

When evaluating sea-ice thickness products from satellite altimetry, it is not sufficient to compare the results solely with submarine or moored ULS measurements. Systematic in situ drilling measurements or measurements by an electromagnetic technique are also needed. Due to the larger fraction of $h_{\mathrm{i}}$ under the sea surface than above it, ULS data are less sensitive to, but still subject to, the same errors, caused by snow loading and assumed sea-water and ice densities, as satellite altimetry data.

The equations to calculate the sea-ice thickness product are different for laser and radar altimetry (Equations (1) and (2)), as the laser altimeter beam is assumed to reflect from the snow surface, and the radar waves from the snow and ice interface. Also, the uncertainty in $h_{\mathrm{i}}$ and the contributions from the different sources of error differ for radar and laser techniques. Figure 6 shows how uncertainties in the assumptions about snow, ice and sea-water density, 
Radar altimetry

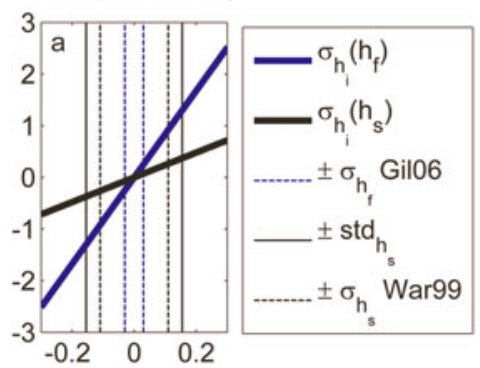

Laser altimetry

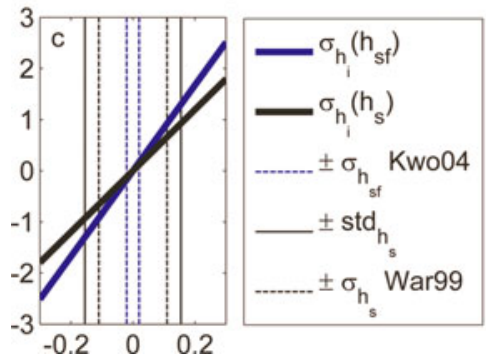

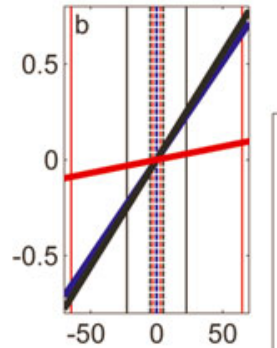
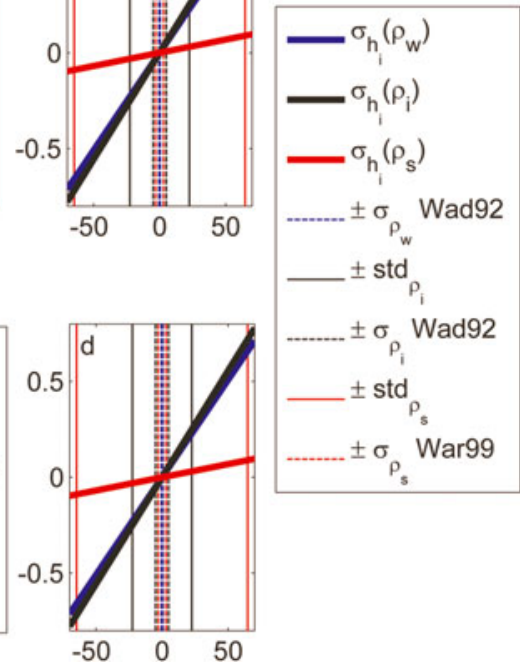

Fig. 6. The sea-ice thickness uncertainty from radar and laser altimetry, as a function of uncertainties in snow and measured freeboard thicknesses ((a) radar, (c) laser) and sea-ice, snow and sea-water densities ((b) radar, (d) laser). As estimates of their natural variability, the solid vertical lines show the standard deviations from the measurements in this study: for snow thickness $0.16 \mathrm{~m}$, for ice density 22 kg $\mathrm{m}^{-3}$ and for snow density $64 \mathrm{~kg} \mathrm{~m}^{-3}$. The dashed vertical lines show variability estimates from the literature, compiled by Giles and others (2007): $\sigma_{h_{\mathrm{s}}}=0.11 \mathrm{~m}$ (Warren and others, 1999), $\sigma_{h_{\mathrm{sf}}}=0.02 \mathrm{~m}$ (Kwok and others, 2004), $\sigma_{h_{\mathrm{f}}}=0.03 \mathrm{~m}(\mathrm{Giles}$ and Hvidegaard, 2006), $\sigma_{\rho_{\mathrm{i}}}=5 \mathrm{~kg} \mathrm{~m}^{-3}$ (Wadhams and others, 1992), $\sigma_{\rho_{\mathrm{s}}}=3 \mathrm{~kg} \mathrm{~m}^{-3}$ (Warren and others, 1999) and $\sigma_{\rho_{\mathrm{w}}}=0.5 \mathrm{~kg} \mathrm{~m}^{-3}$ (Wadhams and others, 1992).

snow thickness and the measured freeboard/snow freeboard propagate to the $h_{\mathrm{i}}$ estimate calculated using the hydrostatic law. The total first-order error in the ice thickness $\left(\sigma_{j}\right.$ being the uncertainty estimate of the $j$ th term) can be calculated using

$$
\sigma^{2}=\sum_{j} \sigma_{j}^{2}\left(\frac{\partial h_{\mathrm{i}}}{\partial j}\right)^{2}
$$

$j=h_{\mathrm{f}}, h_{\mathrm{s}}, \rho_{\mathrm{i}}, \rho_{\mathrm{s}}, \rho_{\mathrm{w}}$ for radar,

$j=h_{\mathrm{sf}}, h_{\mathrm{s}}, \rho_{\mathrm{i}}, \rho_{\mathrm{s}}, \rho_{\mathrm{w}}$ for laser altimetry.

We use this equation to look at the contribution of individual error sources to the $h_{\mathrm{i}}$ uncertainty.

The bulk of the uncertainty in the $h_{\mathrm{i}}$ estimate retrieved from satellite altimetry by both methods is due to the uncertainty in $h_{\mathrm{s}}$ fields and the freeboard/snow-freeboard retrieval error (Giles and others, 2007; Kwok and Cunningham, 2008). For radar, the preferential sampling of thinner ice types and the radar penetration variability can cause an error of a similar order of magnitude (Tonboe and others, 2009). Relating the observed variability within our dataset and some estimates from other studies (Giles and others, 2007) to the sensitivity calculation for $h_{\mathrm{i}}$, following Equation (5), confirms the importance of the accuracy of the assumed $h_{\mathrm{s}}$ in addition to the measured $h_{\mathrm{f}}$ or $h_{\mathrm{sf}}$ (Fig. 6). The estimate of the total error in $h_{\mathrm{i}}$ is $\sim 20 \mathrm{~cm}(36 \mathrm{~cm})$ larger for radar (laser) altimetry than that estimated by Giles and others (2007). This is because measured variability in snow load and ice density in this dataset is larger than the literature values they used.

As ice freeboard is smaller than snow freeboard, laser altimetry is more sensitive to measurement errors than radar. The ice thickness dependence on the error of the measured freeboard/snow freeboard for both techniques is significant. In addition to the spatial variability of freeboard in deformed ice, the instrumental inaccuracy and the uncertainty related to the interaction of the altimeter signal with the atmosphere and different types of surfaces contribute to the error. An estimate for snow load uncertainty following Equation (5) brings about an error of $37 \mathrm{~cm}$ (radar) and $93 \mathrm{~cm}$ (laser), which is much larger than estimated by Alexandrov and others (2010), as the data used in their study consist mostly of level ice with thin snow cover.

The $h_{\mathrm{i}}$ uncertainties caused by errors in measured freeboard/snow freeboard and estimated snow thickness (Fig. 6a and c) are typically 1-2 orders of magnitude larger than those caused by erroneous assumptions about densities (Fig. $6 b$ and d). The density-related errors are close to identical for radar and laser altimetry. The ice thickness dependence on snow density is low, and therefore the uncertainty is only $9 \mathrm{~cm}$, despite the large variability estimate. The snow-loading uncertainty has a seasonal pattern, peaking at the end of the accumulation season in the spring, and being smallest in the autumn, with least variability in the snow thickness (Table 4). The sea-water density uncertainty is of negligible magnitude $(0.5 \mathrm{~cm})$.

The $h_{\mathrm{i}}$ uncertainty dependence on $\rho_{\mathrm{i}}$ uncertainty is similar to $\rho_{\mathrm{w}}$ (Fig. 6), but as the variability is higher, the error grows to $25 \mathrm{~cm}$ for both techniques. The earlier studies estimated $\rho_{\mathrm{i}}$ variability to be much smaller, based on the estimate of Wadhams and others (1992). Alexandrov and others (2010) used the hydrostatic equilibrium to calculate $\rho_{\mathrm{i}}$ for Sever drill data and found variability even larger (std dev. of 689 sites $35.7 \mathrm{~kg} \mathrm{~m}^{-3}$ ) than in the present study (std dev. of 22 sites $22.5 \mathrm{~kg} \mathrm{~m}^{-3}$ ). The spatial variability of the sea-ice density needs to be closely studied and considered in the satellite altimeter-based $h_{\mathrm{i}}$. 
Averaging over large scales makes the effect of the snowload and ice density errors less dramatic than for a point estimate. Our data indicate that over the scales of $0.5 \mathrm{~m}$ to hundreds of metres (the horizontal extent of the drilling transects), the variability of $h_{\mathrm{i}}, h_{\mathrm{s}}, h_{\mathrm{f}}$ and $h_{\mathrm{sf}}$ is constant. As the data were collected to give the best possible description of each ice floe at each ice station, the scales of satellite altimeter footprints were not always obtained.

\section{CONCLUSIONS}

The distributions of the sea-ice thickness and snow depth measured in situ, mostly in Fram Strait, and also the Barents Sea and Svalbard coast, are presented. The measured $h_{\mathrm{i}}$ distributions compare well with earlier published work. The $h_{\mathrm{s}}$ is significantly lower than the values presented by War99 snow climatology for the Arctic basin.

The in situ drilling data averaged spatially over 10-500 m are used to estimate the degree to which the assumption of hydrostatic equilibrium, used in the sea-ice thickness calculation from altimeter data, holds. The hydrostatic equilibrium assumption holds reasonably well for most of the landfast ice, but is less accurate for drift ice. However, for thin ice the relative errors are more prominent than for thick drift ice features in Fram Strait. The deviation between the calculated and measured thickness was on average $49 \mathrm{~cm}$ $\left(23 \%\right.$ of measured $\left.h_{\mathrm{i}}\right)$ for Fram Strait and $36 \mathrm{~cm}(48 \%$ of measured $h_{\mathrm{i}}$ ) for the Svalbard coast and Barents Sea.

The measured snow densities compare well with War99 climatology. The sea-ice densities presented large variability and were lower (901.9 $\mathrm{kg} \mathrm{m}^{-3}$ on average) than literature values (Timco and Frederking, 1996; Kovacs, 1997), resulting from the large portion of light multi-year ice included in the present study.

Given the measured spatial variability of the snow and ice parameters, the uncertainty propagating to the calculated sea-ice thickness was estimated. The variability in ice density is found to be larger than previously reported, which brings about an uncertainty of $25 \mathrm{~cm}$ in the calculated ice thickness product. Based on our data the error in snow thickness is an even larger source of error $(37 \mathrm{~cm}$ (radar) and $93 \mathrm{~cm}$ (laser altimetry)).

\section{ACKNOWLEDGEMENTS}

We thank everybody who participated in collecting the field data, especially the personnel at the Hopen meteorological station, Sverdrup station in Ny-Ålesund, the crews of S/Y Vagabond, R/V Lance and KV Svalbard. The work was supported by the Norwegian Space Center and European Space Agency through the projects PROgramme de Développement d'EXpériences scientifiques (PRODEX) and CryoSat sea-ice validation and process studies in the European Arctic. The measurements were supported by the following projects funded by the Research Council of Norway: Marine ecosystem consequences of climate induced changes in water masses off West-Spitsbergen (MariClim; project No. 165112/S30), Norwegian-Russian Collaboration on Fast Ice Growth and Decay in Kongsfjorden and Grønfjorden (Svalbard) (NoRu fast ice; project No. 178914); Climate effects of reducing black carbon emissions, Atmosphere-Ice-Ocean interaction studies (AIO; project No. 151447), and iAOOS-Norway: Closing the loop (project
No. 176096/S30). EU project DAMOCLES and Center of Ice, Climate and Ecosystems (ICE) at the Norwegian Polar Institute participated in financing the field measurements. We thank A. Nicolaus for structurizing the data and S. Hudson and M. O'Sadnick for useful comments. Reviewers K. Giles, M. Doble, scientific editor N. Hughes, and chief editor M. Granskog are acknowledged for many useful comments that improved the study.

\section{REFERENCES}

Abrahamsen, E.P., S. Østerhus and T. Gammelsrød. 2006. Ice draft and current measurements from the north-western Barents Sea, 1993-1996. Polar Res., 25(1), 25-37.

Ackley, S.F., W.D. Hibler, III, F.K. Kugzruk, A. Kovacs and W.F. Weeks. 1976. Thickness and roughness variations of Arctic multiyear sea ice. CRREL Rep., 76-18.

Alexandrov, V., S. Sandven, J. Wåhlin and O.M. Johannessen. 2010. The relation between sea ice thickness and freeboard in the Arctic. Cryos. Discuss., 4(2), 641-661.

Bowen, R.G. and D.R. Topham. 1996. A study of the morphology of a discontinuous section of a first year arctic pressure ridge. Cold Reg. Sci. Technol., 24(1), 83-100.

Comiso, J.C., P. Wadhams, W.B. Krabill, R.N. Swift, J.P. Crawford and W.B. Tucker, III. 1991. Top/bottom multisensor remote sensing of Arctic sea ice. J. Geophys. Res., 96(C2), 2693-2709.

Connor, L.N., S.W. Laxon, A.L. Ridout, W.B. Krabill and D.C. McAdoo. 2009. Comparison of Envisat radar and airborne laser altimeter measurements over Arctic sea ice. Remote Sens. Environ., 113(3), 563-570.

Doronin, Yu.P. and D.E. Kheisin. 1977. Sea ice. New Delhi, Amerind Publishing Co. Translation of Y.V. Kathavate Morskoi Led, Gidrometeoizdat, Leningrad, 1975.

Gerland, S. and R. Hall. 2006. Variability of fast-ice thickness in Spitsbergen fjords. Ann. Glaciol., 44, 231-239.

Gerland, S. and A.H.H. Renner. 2007. Sea-ice mass-balance monitoring in an Arctic fjord. Ann. Glaciol., 46, 435-442.

Gerland, S., C. Haas, M. Nicolaus and J.-G. Winther. 2004. Seasonal development of structure and optical surface properties of fast ice in Kongsfjorden, Svalbard. In Wiencke, C., ed. The coastal ecosystem of Kongsfjorden, Svalbard. Synopsis of biological research performed at the Koldewey Station in the years 19912003. Bremerhaven, Alfred Wegener Institute for Polar and Marine Research, 26-34.

Gerland, S. and 6 others. 2006. Spring sea ice thickness in the western Fram Strait: preliminary results. In Wadhams, P. and G. Amanatidis, eds. Arctic sea ice thickness: past, present and future. Brussels, European Commission, 158-164.

Gerland, S., A.H.H. Renner, F. Godtliebsen, D. Divine and T.B. Løyning. 2008a. Decrease of sea ice thickness at Hopen, Barents Sea, during 1966-2007. Geophys. Res. Lett., 35(6), L06501. (10.1029/2007GL032716.)

Gerland, S. and 8 others. 2008b. Fast ice evolution in Kongsfjorden compared with other Svalbard fjords. In Azzolini, R., ed.

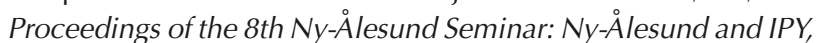
16-17 October 2007, Cambridge, UK. Rome, National Research Council of Italy. Earth and Environment Department, 44-46. (Polarnet Technical Report.)

Giles, K.A. and S.M. Hvidegaard. 2006. Comparison of spaceborne radar altimetry and airborne laser altimetry over sea ice in the Fram Strait. Int. J. Remote Sens., 27(15), 3105-3113.

Giles, K.A. and 8 others. 2007. Combined airborne laser and radar altimeter measurements over the Fram Strait in May 2002. Remote Sens. Environ., 111(2-3), 182-194.

Giles, K.A., S.W. Laxon and A.P. Worby. 2008a. Antarctic sea ice elevation from satellite radar altimetry. Geophys. Res. Lett., 35(3), L03503. (10.1029/2007GL031572.) 
Giles, K.A., S.W. Laxon and A.L. Ridout. 2008b. Circumpolar thinning of Arctic sea ice following the 2007 record ice extent minimum. Geophys. Res. Lett., 35(22), L22502. (10.1029/2008GL035710.)

Gloersen, P. and W.J. Campbell. 1991. Recent variations in Arctic and Antarctic sea-ice covers. Nature, 352(6330), 33-36.

Haas, C. 2004. Late-summer sea ice thickness variability in the Arctic Transpolar Drift 1991-2001 derived from ground-based electromagnetic sounding. Geophys. Res. Lett., 31(9), L09402. (10.1029/2003GL019394.)

Haas, C., S. Goebel, S. Hendricks, T. Martin, A. Pfaffling and C. von Saldern. 2006. Airborne electromagnetic measurements of sea ice thickness: methods and applications. In Wadhams, P. and G. Amanatidis, eds. Arctic sea ice thickness: past, present and future. Brussels, European Commission.

Hansen, E., T.B. Løyning, S. Gerland, and H. Goodwin. 2004. Arctic sea ice thickness variability observed over a decade in the Fram Strait. In Arctic Climate System Study (ACSYS). Progress in Understanding the Arctic Climate System: the ACSYS Decade and Beyond. Proceedings of the ACSYS FInal Science Conference.

Ivanov, B.V., S. Gerland, J.-G. Winther and H. Goodwin. 2003. Energy exchange processes in the marginal ice zone of the Barents Sea, Arctic Ocean, during spring 1999. J. Glaciol., 49(166), 415-419.

Johannessen, O.M., E.V. Shalina and M.W. Miles. 1999. Satellite evidence for an Arctic sea ice cover in transformation. Science, 286(5446), 1937-1939.

Kovacs, A. 1997. Estimating the full-scale flexural and compressive strength of first-year sea ice. J. Geophys. Res., 102(C4), 8681-8689.

Kurtz, N.T. and 6 others. 2009. Estimation of sea ice thickness distributions through the combination of snow depth and satellite laser altimetry data. J. Geophys. Res., 114(C10), C10007. (10.1029/2009JC005292.)

Kwok, R. and G.F. Cunningham. 2008. ICESat over Arctic sea ice: estimation of snow depth and ice thickness. J. Geophys. Res., 113(C8), C08010. (10.1029/2008JC004753.)

Kwok, R. and D.A. Rothrock. 2009. Decline in Arctic sea ice thickness from submarine and ICESat records: 1958-2008. Geophys. Res. Lett., 36(15), L15501. (10.1029/2009GL039035.)

Kwok, R., H.J. Zwally and D. Yi. 2004. ICESat observations of Arctic sea ice: a first look. Geophys. Res. Lett., 31(16), L16401. (10.1029/2004GL020309.)
Laxon, S., N. Peacock and D. Smith. 2003. High interannual variability in sea ice thickness in the Arctic region. Nature, 425(6961), 947-950.

Melling, H., D.R. Topham and D. Riedel. 1993. Topography of the upper and lower surfaces of 10 hectares of deformed sea ice. Cold Reg. Sci. Technol., 21(4), 349-369.

Nicolaus, M., C. Haas and J. Bareiss. 2003. Observations of superimposed ice formation at melt-onset on fast ice on Kongsfjorden, Svalbard. Phys. Chem. Earth, 28(28-32), 1241-1248.

Pedersen, C.A., R. Hall, S. Gerland, A.H. Sivertsen, T. Svenøe and C. Haas. 2009. Combined airborne profiling over Fram Strait sea ice: fractional sea-ice types, albedo and thickness measurements. Cold Reg. Sci. Technol., 55(1), 23-32.

Romanov, I.P. 1996. Atlas of ice and snow of the Arctic Basin and Siberian Shelf seas. Second edition. Fair Lawn, NJ, Backbone Publishing Company.

Sandven, S. and O.M. Johannessen. 2006. Sea ice monitoring by remote sensing. In Gower, J.F.R., ed. Manual of remote sensing, Vol. 6. Remote sensing of the marine environment. Third edition. Bethesda, MA, American Society for Photogrammetry and Remote Sensing, 241-283.

Spreen, G., S. Kern, D. Stammer and E. Hansen. 2009. Fram Strait sea ice volume export estimated between 2003 and 2008 from satellite data. Geophys. Res. Lett., 36(19), L19502. (10.1029/2009GL039591.)

Timco, G.W. and R.P. Burden. 1997. An analysis of the shapes of sea ice ridges. Cold Reg. Sci. Technol., 25(1), 65-77.

Timco, G.W. and R.M.W. Frederking. 1996. A review of sea ice density. Cold Reg. Sci. Technol., 24(1), 1-6.

Tonboe, R.T., L.T. Pedersen and C. Haas. 2009. Simulation of the satellite radar altimeter sea ice thickness retrieval uncertainty. Cryos. Discuss., 3(2), 513-559.

Vinje, T. and Ø. Finnekåsa. 1986. The ice transport through the Fram Strait. Nor. Polarinst. Skr. 186, 1-39.

Vinje, T., N. Nordlund and Ø.S. Kvambekk. 1998. Monitoring ice thickness in Fram Strait. J. Geophys. Res., 103(C5), 10,437-10,450.

Wadhams, P., W.B. Tucker, III, W.B. Krabill, R.N. Swift, J.C. Comiso and N.R. Davis. 1992. Relationship between sea ice freeboard and draft in the Arctic Basin, and implications for ice thickness monitoring. J. Geophys. Res., 97(C12), 20,325-20,334.

Warren, S.G. and 6 others. 1999. Snow depth on Arctic sea ice. J. Climate, 12(6), 1814-1829. 